\title{
Lucas Nogueira Garcez: In memoriam
}

\author{
Justo Pinheiro da Fonseca \\ Presidente do Conselho de Administração da EAESP/FGY.
}

Ao deter-me entre as minhas urgencias e obrigaçóes imediatas, para escrever esta nota de profundo pesar pelo. desaparecimento do grande amigo e da excepcional pessoa humana, Prof. Lucas Garcez, preocupou-me desde logo a sua personalidade que, sob uma aparéncia simples, escondia caracteristicas surpreendentes: sob a modéstia, a segurança do próprio valor isenta de qualquer orgulho; polidez impecavel, aparencia de tender sempre a concordar e de não ser capaz de se opor e negar, estava sempre em guarda com resistencia inabalavel, firme ante qualquer ameaça de ataque à zona inexpugnàvel da sua consciencia - entre o sorriso humano que a todos recebe com igualdade, e o terreno de acesso à intimidade, uma barreira aos que tentam viola-la; contido sob um rigoroso sistema. de freios e controle, a bondade militante e a capacidade de comover-se intensamente sem prantos públicos; severo consigo mesmo e compreensivo na relação com as pessoas.

Essa complexidade ou este jogo de contrários resolve-se, pois, na compreensão do homem público - professor, engenheiro, secretaino de Estado do governador que foi Lucas Garcez.

O grande legado que nos fica do Prof. Garcez e a liçao de que por mais eminente ou marcante a posiçáo a que o cidadão seja levado, nāo pode ele deixar de carregar no seu proprio espinito um nucleo de idéias fundamentais para a firmeza de sua dîreção, evitando a inconstância da conduta em face da versatilidade das circunstâncias.

Não podemos desconhecer que a funcão pública é o exercicio de um mandato.

Garcez se considerou 110 governo um homem que teve do povo a incumbencia de ser instrumento do bem comum, $e$ não de se servir do poder pelo que possa the proporcionar em interesse pessoal.

Cabe-nos registrar, entre as muitas realizaçóes da sua vida püblica, a sua participaçăo decisiva como governador

na fundacão da EAESP, cuja vida ele sempre acompanhou na qualidade de membro do conselho de

Administração, participando de seus sucessos e das suas dificuldades, com seus conselhos, sua dedicação e disponibilidade para encontrar as soluçoes necessárias.

Näo nos faltam razöes para deplorar a perda do grande companheiro.

Mais que uma viva e cultivada inteligencia e um lucido espinito, foi um generoso e delicado coraçāo que deixou de pulsar ao nosso lado, na luta de todas as horas.

So nos pode consolar a idéia de que o seu nome e o seu exemplo ficarão como estímulo aos contemporaneos e como lição aos que nos sucederam. 